\title{
Conservative versus Radical Management of Morbidly Adherent Placenta: An Audit
}

\author{
MUNA A.M. ALAWIETI, M.Sc.; EMADA. FYALA, M.D.; KHALID S. ISMAIL, M.D. and \\ AHMED M.M. BADAWY, M.D.
}

The Department of Obstetrics \& Gynecology, Faculty of Medicine, Mansoura University

\begin{abstract}
Background: Maternal and neonatal morbidity and mortality are associated with abnormal placentation and obstetric hemorrhage. To reduce morbidity and mortality in morbidly adherent placentas, a high index of suspicion, early antenatal diagnosis, adequate patient counselling, scheduled surgery at a well-equipped institution, and anticipation of high volume blood transfusion are the essential steps.

Aim of Study: The aim of this study was to reach the best way of management of abnormal adherent placentathrough evaluation of conservative and radical management of cases ofplacenta accreta over last three years in Mansoura University Hospital.

Patients and Methods: A retrospective observational study conducted in Obstetrics and Gynecology Dept. of Mansoura University Hospital. We reviewed the medical records of 250 women who diagnosed as invasive placenta from the beginning of (2017) to the end of (2019). The main aim to reach the best way of management of abnormal adherent placenta through evaluation of conservative and radical management of cases of placenta accreta over last three years in Mansoura University.

Results: There was statistically significant higher median volume blood loss, packed RBCs units, fresh frozen plasma and platelet units with radical management than with conservative management. Regarding maternal complications, bladder injury, ureteric injury, major vessel injury, wound infection, coagulopathy, re-admission and ICU admission were higher incidence among cases in radical group than cases with conservative management. Grade 3 was present among cases with radical management only $(30.5 \%)$ while grade 1 was higher among cases with conservative management $96.9 \%$

Conclusion: According to our study, conservative management in G1 (placenta accreta) is the recommended management option, well-planned cesarean hysterectomy in G3 (placenta percreta) is the only management option. While G2 (placenta increta) can be managed either radically or conservatively according to bleeding degree and bleeding control.
\end{abstract}

Key Words: Morbidly adherent placenta-Conservative Radical.

Correspondence to: Dr. Muna A.M. Alawieti, The Department of Obstetrics \& Gynecology, Faculty of Medicine, Mansoura University

\section{Introduction}

MORBIDLY adherent placenta (MAP), a relatively new term, referred to three specific types of abnormal placentation: Placenta accreta, increta, and percreta [1]. Conservative management of placenta accreta has been proposed to reduce morbidity and mortality in cases of placenta percreta invading adjacent organs. Typically, conservative approaches involve delivery of the neonate followed by closure of the uterine incision with the placenta left in situ, with or without adjuvant measures, such as use of uterine compression sutures, devasculariztion or embolization. The placenta is allowed to resorb over time [2]. All conservative managements have a favorable outcome in more than $90 \%$ of reported cases with a rate of maternal morbidity of $6 \%$ [3]

Conservative management described any approach where by hysterectomy was avoided. It was utilized when intraoperative findings suggested that hysterectomy carried an unacceptably high risk of hemorrhage or adjacent tissue injury that may be mitigated by leaving the placenta in situ [2].

Hysterectomy is standard treatment for MAP in many countries, but there are some publications describing a high rate of false positives after histological analysis [4]. Thus it is possible that numerous unnecessary hysterectomy procedures are performed, causing irreversible damage and mutilation. For this reason, there is particular interest in validating prenatal findings by surgical staging [5].

\section{Patients and Methods}

Our retrospective observational study was conducted in Obstetrics and Gynecology Dept. of Mansoura University Hospital. We reviewed the- 
medical records of 250 women who were diagnosed as invasive placenta from the beginning of (2017) to the end of (2019).

\section{Ethical considerations:}

The Medical Research Committee of the Faculty of Medicine accepted the study protocol. At all levels of the study, confidentiality and personal privacy were protected. The information gathered was not utilized for any other purpose.

\section{Methods:}

The case records of all women identified as MAP from the hospital registers were retrieved after approval of the Medical Research Committee of Faculty of Medicine to carry out this study.

Two hundred and fifty patients with the diagnosis of placenta accreta, increta and percreta were included in the study. The criterion for diagnosis of MAP was taken as at least one of the following:

1- Manual removal of the placenta being partially or totally impossible.

2- Evidence of gross placental invasion at surgery.

3- In women with an ultrasound diagnosis of MAP confirmed by failed attempts to remove the placenta during the third stage of labor.

4- Histopathological confirmation of hysterectomy specimen.

The patients were divided into two groups: Group 1, in whom the conservative management was applied and Group 2, those in whom the radical management was applied.

Maternal demographic data including age, gestational age and previous cesarean delivery or other uterine surgery, details of medical and obstetric history and information on the intraoperative and post-operative were noted.

From the operative notes, data on placental location, estimated blood loss, units of blood transfusion required and surgical procedure carried out tocontrol bleeding was retrieved.

Post-operative need for intensive care unit (ICU) admission and other maternal complications were recorded. Perinatal mortality and neonatal outcomes for birth weights, nursery admission, and nursery stay in both groups was also noted.

\section{Statistical analysis:}

Data were fed to the computer and analyzed using IBM SPSS Corp. Released 2013. IBM SPSS Statistics for Windows, Version 22.0. Armonk, NY: IBM Corp. Qualitative data were described using number and percent. Quantitative data were de- scribed using median (minimum and maximum) for non-parametric data and mean, standard deviation for parametric data after testing normality using Kolmogrov-Smirnov test. Significance of the obtained results was judged at the (0.05) level.

\section{Results}

Table (1) showed that there was statistically significant association between age of females, gravidity, parity, number of previous deliveries, surgical history, gestational age and number of previous deliveries. Mean age of the studied cases was higher among cases with radical treatment (33.31) versus (30.32) among conservative group. Median gravidity, parity, number of previous deliveries and median number of previous CS were higher among cases with radical treatment than conservative treatment while gestational age was lower among radical management than conservative (36.54 versus 36.92 respectively) (Table 1 ).

There was statistically significant higher mean HB level among cases with conservative treatment pre and post-operative. Mean difference of hemoglobin level pre and post-operative indicated statistically significant higher value among cases with radical treatment than conservative (Table 2).

Table (1): Demographic, medical and obstetric history distribution among studied cases according to management technique.

\begin{tabular}{|c|c|c|c|}
\hline & $\begin{array}{l}\text { Conservative } \\
\text { Management }\end{array}$ & $\begin{array}{c}\text { Radical } \\
\text { Management }\end{array}$ & $\begin{array}{c}\text { Test of } \\
\text { significance }\end{array}$ \\
\hline \multicolumn{4}{|l|}{ Agelyears: } \\
\hline Mean \pm SD (Min-Max) & $30.32 \pm 5.46$ & $33.31 \pm 4.69$ & $\begin{array}{l}t=3.79 \\
p<0.001 *\end{array}$ \\
\hline \multicolumn{4}{|l|}{ Gravidity: } \\
\hline Median (range) & $4(2-13)$ & $5(3-10)$ & $\begin{array}{l}\mathrm{Z}=4.74 \\
p<0.001 *\end{array}$ \\
\hline \multicolumn{4}{|l|}{ Parity: } \\
\hline Median (range) & $2(1-7)$ & $3(1-5)$ & $\begin{array}{l}\mathrm{Z}=4.14 \\
p<0.001 *\end{array}$ \\
\hline \multicolumn{4}{|l|}{$\begin{array}{l}\text { Number of previous } \\
\text { deliveries: }\end{array}$} \\
\hline 1 & $43(22.5)$ & $4(6.8)$ & $\mathrm{MC}$ \\
\hline 2 & $70(36.6)$ & $13(22)$ & $p=0.002^{*}$ \\
\hline 3 & $52(27.2)$ & $26(44.1)$ & \\
\hline 4 & $21(11)$ & $14(23.7)$ & \\
\hline 5 & $3(1.6)$ & $2(3.4)$ & \\
\hline 6 & $2(1.0)$ & 0 & \\
\hline \multicolumn{4}{|l|}{ Gestational age/week: } \\
\hline Mean \pm SD & $36.92 \pm 0.85$ & $36.54 \pm 1.01$ & $\begin{array}{l}t=2.86 \\
p=0.005 *\end{array}$ \\
\hline \multicolumn{4}{|l|}{ Medical history: } \\
\hline DM & $3(1.6)$ & $1(1.7)$ & $\mathrm{FET}, p=1.0$ \\
\hline Hypertension & $15(7.9)$ & $3(5.1)$ & $\begin{array}{l}\chi=0.517 \\
p=0.472\end{array}$ \\
\hline Thyroid & $1(0.5)$ & $0(0.0)$ & $\mathrm{FET}, p=1.0$ \\
\hline $\begin{array}{l}\text { SD }: \text { Standard deviation. } \\
\mathrm{Z} \quad: \text { Mann Whitney U tes } \\
t \quad: \text { Student } t \text {-test. } \\
\text { MC }: \text { Monte Carlo test. }\end{array}$ & $\begin{array}{r}\text { FET: Fi } \\
\chi \\
* \text { Statist } \\
\text { DM: Di }\end{array}$ & $\begin{array}{l}\text { cher exact } \\
=\text { Chi-Squa } \\
\text { cally signif } \\
\text { betes melli }\end{array}$ & $\begin{array}{l}\text { test. } \\
\text { ant if } p<0.05 \text {. }\end{array}$ \\
\hline
\end{tabular}


Table (2): Mean hemoglobin level between cases with radical and conservative treatment.

\begin{tabular}{lccc}
\hline $\begin{array}{l}\text { HB }(\mathrm{gm} / \mathrm{dl}) \\
\text { Mean } \pm \text { SD }\end{array}$ & $\begin{array}{c}\text { Conservative } \\
\text { Management }\end{array}$ & $\begin{array}{c}\text { Radical } \\
\text { Management }\end{array}$ & $\begin{array}{c}\text { Test of } \\
\text { significance }\end{array}$ \\
\hline Pre-operative & $10.68 \pm 0.63$ & $10.34 \pm 0.77$ & $\begin{array}{l}t=3.54 \\
p<0.001 *\end{array}$ \\
Post-operative & $8.97 \pm 0.74$ & $7.97 \pm 0.96$ & $\begin{array}{l}t=8.46 \\
p<0.001 *\end{array}$ \\
Difference & $1.71 \pm 0.53$ & $2.56 \pm 0.99$ & $\begin{array}{l}t=8.49 \\
p<0.001 *\end{array}$ \\
\hline
\end{tabular}

$t$ : Student $t$-test.

*Statistically significant if $p<0.05$.

Hb: Haemoglobin.

Table (3) illustrated that there was statistically significant relation between cases with conservative and radical treatment regarding ultrasound findings; $86.4 \%$ of cases with radical treatment had placenta previa complete centralis versus $62.3 \%$ of cases with conservative treatment. Among cases with radical management, $8.5 \%$ have placenta previa major degree anterior and $5.1 \%$ placenta previa major degree posterior versus $26.2 \%$ and $11.5 \%$ of the cases with conservative management, respectively (Table 3 ).

Regarding type of incision and mode of delivery with $93.2 \%$ of cases with radical management had Pfannenstiel incision versus $99.5 \%$ of cases with conservative management. Among cases with radical management, $98.3 \%$ had upper segment delivery versus $88 \%$ of cases with conservative management. There was statistically significant between cases with conservative and radical treatment (Table 4).

There was no statistically significant difference between cases with conservative and radical management regarding bilateral uterine arteryligation and bilateral internal iliac artery ligation. The only statistically significant difference between conservative and radical management was frequency ofhemostatic sutures at placental bed, with higher frequency among cases with conservative management (70.7 versus 20.3 for radical management, respectively) (Table 5).

There was statistically significant difference between cases with conservative and radical management $(p<0.001)$. Grade 3 (percreta) was presentamong cases with radical treatment only $(30.5 \%)$ while grade 1 (accreta) was higher among cases with conservative management $96.9 \%$ (Table 6).

Table (7) demonstrated that there was statistically significant higher median volume blood loss, packed RBCs units, fresh frozen plasma and platelet units with radical management than with conservative management (Table 7).

There was statistically significant difference between cases with conservative and radical management regarding the following maternal complications; bladder injury, ureteric injury, major vessel injury, wound infection, coagulopathy, re-admission and ICU admission among cases with higher incidence of complications among cases with radical management than cases with conservative management (Table 8).

In addition, there was statistically significant association between frequencies of NICU admission among cases with radical treatment than conservative management (22\% versus $11.6 \%$, respectively) (Table 9).

Table (3): Ultrasonography, placenta bed Doppler findings, final diagnosis distribution according to management type of the studied cases.

\begin{tabular}{|c|c|c|c|}
\hline $\begin{array}{l}\text { Ultrasonography and } \\
\text { Doppler U/S }\end{array}$ & $\begin{array}{l}\text { Conservative } \\
\text { Management }\end{array}$ & $\begin{array}{c}\text { Radical } \\
\text { Management }\end{array}$ & $\begin{array}{c}\text { Test of } \\
\text { significance }\end{array}$ \\
\hline $\begin{array}{l}\text { Placenta previa } \\
\text { complete centralis }\end{array}$ & $119(62.3)$ & $51(86.4)$ & \multirow{3}{*}{$\begin{array}{l}\chi^{2}=12.15 \\
p=0.002^{*}\end{array}$} \\
\hline $\begin{array}{l}\text { Placenta previa major } \\
\text { degree anterior }\end{array}$ & $50(26.2)$ & $5(8.5)$ & \\
\hline $\begin{array}{l}\text { Placenta previa major } \\
\text { degree posterior }\end{array}$ & $22(11.5)$ & $3(5.1)$ & \\
\hline \multicolumn{3}{|l|}{ Lacuna: } & \multirow{3}{*}{$\begin{array}{l}\chi^{2}=26.31 \\
p=0.001 *\end{array}$} \\
\hline Present & $113(59.2)$ & $56(94.9)$ & \\
\hline Absent & $78(40.8)$ & $3(5.1)$ & \\
\hline \multicolumn{4}{|l|}{ Retroplacental } \\
\hline Present & $9(4.7)$ & 0 & \multirow{2}{*}{$\begin{array}{l}\chi^{2}=2.88 \\
p=0.09\end{array}$} \\
\hline Absent & $182(95.3)$ & $59(100)$ & \\
\hline \multicolumn{4}{|l|}{ Retroplacenta } \\
\hline $\begin{array}{l}\text { Imyometrial thickness: } \\
\text { Thin }\end{array}$ & $146(76.4)$ & $24(40.7)$ & \multirow{2}{*}{$\begin{array}{l}\chi^{2}=26.49 \\
p<0.001 *\end{array}$} \\
\hline Lost & $45(23.6)$ & $35(59.3)$ & \\
\hline \multicolumn{3}{|l|}{ Uterovesical interface: } & \multirow{3}{*}{$\begin{array}{l}\chi^{2}=59.19 \\
p<0.001 *\end{array}$} \\
\hline No & $171(89.5)$ & $25(42.4)$ & \\
\hline Yes & $20(10.5)$ & $34(57.6)$ & \\
\hline \multicolumn{3}{|l|}{$\begin{array}{l}\text { Uterovesical } \\
\text { hypervascularity: }\end{array}$} & \multirow{3}{*}{$\begin{array}{l}\chi^{2}=26.91 \\
p<0.001 *\end{array}$} \\
\hline No & $79(41.4)$ & $3(5.1)$ & \\
\hline Yes & $112(58.6)$ & $56(94.9)$ & \\
\hline
\end{tabular}

Table (4): Type of incision and mode of delivery between conservative and radical management.

\begin{tabular}{lll}
\hline & $\begin{array}{c}\text { Conservative } \\
\text { Management }\end{array}$ & $\begin{array}{c}\text { Radical } \\
\text { Management }\end{array}$ \\
\hline $\begin{array}{l}\text { Type of incision: } \\
\text { Pfannenstiel incision }\end{array}$ & $190(99.5)$ & $55(93.2)$ \\
$\quad$ Midline sub-umbilical & $1(0.5)$ & $4(6.8)$ \\
Mode of delivery: & & \\
Lower & $23(12.0)$ & $1(1.7)$ \\
Upper & $168(88)$ & $58(98.3)$ \\
\hline
\end{tabular}


Table (5): Surgical injury distribution among studied cases according to type of management.

\begin{tabular}{|c|c|c|c|}
\hline & $\begin{array}{l}\text { Conservative } \\
\text { Management } \mathrm{I}\end{array}$ & $\begin{array}{l}\text { Radical } \\
\text { Managemen }\end{array}$ & $\begin{array}{c}\text { Test of } \\
\text { significance }\end{array}$ \\
\hline $\begin{array}{l}\text { Bilateral uterine } \\
\text { artery ligation }\end{array}$ & $151(79.1)$ & $41(69.5)$ & $\begin{array}{l}\chi^{2}=2.32 \\
p=0.128\end{array}$ \\
\hline $\begin{array}{l}\text { Bilateral internal iliac } \\
\text { artery ligation }\end{array}$ & $156(81.7)$ & $44(74.6)$ & $\begin{array}{l}\chi^{2}=1.42 \\
p=0.233\end{array}$ \\
\hline $\begin{array}{l}\text { Conservative: } \\
\text { - Hemostatic sutures at } \\
\text { placental bed }\end{array}$ & 135 (70.7) & $12(20.3)$ & $\begin{array}{l}\chi^{2}=47.16 \\
p<0.001^{*}\end{array}$ \\
\hline - Resection isthmosutures & $1(0.5)$ & 0 & $\begin{array}{l}\text { FET } \\
p \overline{\overline{2}} 1.0\end{array}$ \\
\hline $\begin{array}{l}\text { - Resection of Lower } \\
\text { uterine segment }\end{array}$ & 15 (7.9) & $1(1.7)$ & $\begin{array}{l}\chi=2.85 \\
p=0.091\end{array}$ \\
\hline
\end{tabular}

Table (6): Intra-operative placental grading distribution according to type of management.

\begin{tabular}{clll}
\hline & $\begin{array}{c}\text { Conservative } \\
\text { Management }\end{array}$ & $\begin{array}{c}\text { Radical } \\
\text { Management significance }\end{array}$ & $\begin{array}{c}\text { Test of } \\
\text { Intra-operative grading } \\
\text { according to FIGO: }\end{array}$ \\
$\quad$ & & & \\
G1 (accreta) & $185(96.9)$ & $8(13.6)$ & $\chi^{2}=179.31$ \\
G2 (increta) & $6(3.1)$ & $33(55.9)$ & $p<0.001 *$ \\
G3 (percreta) & 0 & $18(30.5)$ & \\
\hline
\end{tabular}

Table (7): Blood transfusion distribution according to management type of the studied cases.

\begin{tabular}{|c|c|c|c|}
\hline & $\begin{array}{l}\text { Conservative } \\
\text { Management }\end{array}$ & $\begin{array}{c}\text { Radical } \\
\text { Management }\end{array}$ & $\begin{array}{c}\text { Test of } \\
\text { significance }\end{array}$ \\
\hline $\begin{array}{l}\text { Volume blood loss } \\
\text { Median (range) }\end{array}$ & $4(3-6)$ & $6(4-10)$ & $\begin{array}{l}\mathrm{Z}=9.73 \\
p<0.001 *\end{array}$ \\
\hline \multicolumn{4}{|l|}{ Blood transfusion: } \\
\hline $\begin{array}{l}\text { Packed RBCs units } \\
\text { Median (range) }\end{array}$ & $6(4-8)$ & $8(5-13)$ & $\begin{array}{l}\mathrm{Z}=8.6 \\
p<0.001^{*}\end{array}$ \\
\hline $\begin{array}{l}\text { Fresh frozen plasma } \\
\text { Median (range) }\end{array}$ & $2(1-4)$ & $3(2-7)$ & $\begin{array}{l}\mathrm{Z}=7.08 \\
p<0.001^{*}\end{array}$ \\
\hline $\begin{array}{l}\text { Platelet units } \\
\text { Median (range) }\end{array}$ & $2(1-4)$ & $3(2-11)$ & $\begin{array}{l}\mathrm{Z}=4.45 \\
p<0.001^{*}\end{array}$ \\
\hline
\end{tabular}

Table (8): Maternal complications distribution among studied cases according to type of management.

\begin{tabular}{|c|c|c|c|}
\hline $\begin{array}{l}\text { Maternal } \\
\text { complications }\end{array}$ & $\begin{array}{l}\text { Conservative } \\
\text { Management }\end{array}$ & $\begin{array}{c}\text { Radical } \\
\text { Management }\end{array}$ & $\begin{array}{c}\text { Test of } \\
\text { significance }\end{array}$ \\
\hline Bladder injury & $12(6.3)$ & $29(49.2)$ & $\begin{array}{l}\chi^{2}=60.42 \\
p<0.001^{*}\end{array}$ \\
\hline Ureteric injury & $1(0.5)$ & $9(15.3)$ & $\begin{array}{l}\chi^{2}=25.47 \\
p<0.001 *\end{array}$ \\
\hline Major vessel injury & $1(0.5)$ & $3(5.1)$ & FET, $p=0.042^{*}$ \\
\hline Intestinal injury & $1(0.5)$ & $1(1.7)$ & FET, $p=0.417$ \\
\hline Broad ligament ligation & $1(0.5)$ & $0(0.0)$ & $\mathrm{FET}, p=1.0$ \\
\hline Re-exploration & $0(0.0)$ & $2(3.4)$ & FET, $p=0.06$ \\
\hline Wound infection & $2(1.0)$ & $5(8.5)$ & $\begin{array}{l}\chi^{2}=9.14 \\
p=0.003^{*}\end{array}$ \\
\hline Coagulopathy & $3(1.6)$ & $20(33.9)$ & $\begin{array}{l}\chi^{2}=56.39 \\
p<0.001^{*}\end{array}$ \\
\hline Re-admission & $3(1.6)$ & $5(8.5)$ & $\begin{array}{l}\chi^{2}=6.94 \\
p=0.008^{*}\end{array}$ \\
\hline ICU admission & $16(8.4)$ & $56(94.9)$ & $\begin{array}{l}\chi^{2}=164.62 \\
p<0.001^{*}\end{array}$ \\
\hline
\end{tabular}

ICU: Intensive Care Unit.
Table (9): Fetal outcome distribution among studied cases according to type of management.

\begin{tabular}{|c|c|c|c|}
\hline & $\begin{array}{l}\text { Conservative } \\
\text { Management }\end{array}$ & $\begin{array}{c}\text { Radical } \\
\text { Management }\end{array}$ & $\begin{array}{c}\text { Test of } \\
\text { significance }\end{array}$ \\
\hline \multicolumn{4}{|l|}{ Gender of baby: } \\
\hline Male & $103(53.9)$ & $27(45.8)$ & \multirow{3}{*}{$\begin{array}{l}\mathrm{MC} \\
p=0.531\end{array}$} \\
\hline Female & $86(45)$ & $31(52.5)$ & \\
\hline Twins & $1(0.5)$ & $1(1.7)$ & \\
\hline \multicolumn{3}{|l|}{ NICU admission: } & \multirow{3}{*}{$\begin{array}{l}\chi^{2}=4.01 \\
p=0.045^{*}\end{array}$} \\
\hline$-\mathrm{ve}$ & $167(88.4)$ & $46(78.0)$ & \\
\hline+ ve & $22(11.6)$ & $13(22.0)$ & \\
\hline \multicolumn{3}{|l|}{ APGAR score $(<7)$ : } & \multirow{3}{*}{$\begin{array}{l}\chi^{2}=3.53 \\
p=0.06\end{array}$} \\
\hline At 1 minute & $166(87.8)$ & $46(78.0)$ & \\
\hline At 5 minute & $23(12.2)$ & $13(22.0)$ & \\
\hline \multicolumn{3}{|l|}{ Respiratory morbidity: } & \multirow{3}{*}{$\begin{array}{l}\chi^{2}=2.69 \\
p=0.101\end{array}$} \\
\hline- ve & $164(86.8)$ & $46(78)$ & \\
\hline +ve & $25(13.2)$ & $13(22)$ & \\
\hline \multicolumn{4}{|l|}{ Mortality of baby: } \\
\hline No & $188(98.4)$ & $58(98.3)$ & \multirow{2}{*}{$\begin{array}{l}\text { FET } \\
p=1.0\end{array}$} \\
\hline Yes & $3(1.6)$ & $1(1.7)$ & \\
\hline
\end{tabular}

NICU: Neonatal Intensive Care Unit.

\section{Discussion}

In our study, there was statistically significant association between ages of females, gravidity, parity, number of previous deliveries, surgical history, gestational age and number of previous deliveries and type of MAP management. Mean age of the studied cases was higher among cases with radical group (33.31) versus (30.32) among conservative treatment group. This came in consistence to Elkhateeb in Egypt [6] who recorded that the mean age in radical group was 34.1 while conservative group was 33.2. However, Kutuket al., [7] found that the primary demographic data did not differ between treatment groups. Median gravidity, parity, number of previous deliveries and median number of previous CSs were higher among cases with radical treatment than conservative treatment; these findings were in agreement with Elkhateeb [6]. In contrast, mean age and parity appears to be similar as in many other studies (Shabab and Naqvi) with a minor difference, and does not appear to influence directly on the maternal outcome as in our study [8]. While gestational age was lower among radical management than conservative (36.54 versus 36.92 , respectively). Similarly, Elkhateeb [6] reported that gestational age was lower among radical group (36.4) versus 37.1 in conservative group.

The results of the current study confirm that old age, multiparty, placenta previa, andprevious uterine surgeries were significant risk factors for placenta accreta, which supports previous literature results $[9,10]$. In the current study, there was statistically significant higher mean $\mathrm{Hb}$ level among 
cases with conservative treatment pre-operative $(10.68 \mathrm{gm} / \mathrm{dl})$ and post-operative $(8.97 \mathrm{gm} / \mathrm{dl})$ than radical treatment pre-operative $(10.34 \mathrm{gm} / \mathrm{dl})$ and post-operative $(7.97 \mathrm{gm} / \mathrm{dl})$. In contrast, mean difference of hemoglobin level pre and post-operative indicate statistically significant higher value among cases with radical treatment (2.56) than conservative (1.7). Kutuk et al., [7] recorded in their study slightly higher mean $\mathrm{Hb}$ level among cases with conservative treatment pre-operative $(12 \mathrm{gm} / \mathrm{dl})$ and post-operative $(10.0 \mathrm{gm} / \mathrm{dl})$ than radical treatment pre-operative $(11.9 \mathrm{gm} / \mathrm{dl})$ and post-operative $(10.1 \mathrm{gm} / \mathrm{dl})$. In contrast, mean difference of $\mathrm{Hb}$ level pre and post-operative indicate statistically significant higher value among cases with conservative treatment (2.0) than radical (1.7).

Regarding ultrasound findings, among cases with radical treatment $86.4 \%$ have placenta previa complete centralis versus $62.3 \%$ of cases with conservative treatment. Among cases with radical management, $8.5 \%$ have Placenta previa major degree anterior and $5.1 \%$ Placenta previa major degree posterior versus $26.2 \%$ and $11.5 \%$ of the cases with conservative management, respectively.

Concerning type of incision and mode of delivery, there was statistically significant relation between types of MAP management and type of incision and mode of delivery, $93.2 \%$ of cases with radical management have Pfannenstiel incision versus $99.5 \%$ of cases with conservative management. Among cases with radical management, $98.3 \%$ had upper segment delivery versus $88 \%$ of cases with conservative management.

As regard surgical injury distribution among studied cases according to type of management, there was no statistically significant difference between cases with conservative and radical management. Where $76.8 \%$ of the studied cases have bilateral uterine artery ligation, $80.0 \%$ bilateral internal iliac artery ligation, $58.8 \%$ hemostatic sutures at placental bed, $23.6 \%$ CS hysterectomy, $6.4 \%$ resection of lower uterine segment and $0.4 \%$ resection isthmosutures. Biler et al., [11] in their study population, $78 \%$ women were managed conservatively. The placenta was removed after delivery in all these patients. According to the degree of bleeding, uterine compression sutures, bilateral uterine artery ligation, bilateral hypogastric artery ligation were used and if needed, two or more techniques were performed. Due to hemodynamic instability, four patients underwent hysterectomy during cesarean section and four underwent hysterectomy during early re-operation. Among patients treated conservatively, two experienced wound infection, three experienced renal tract injury and two admitted ICU.

While in other study, Nasrullah et al., [12] reported that majority of patients $(74 \%)$ underwent caesarean hysterectomy without trial removal of the placenta. Placental removal was performed in $(26 \%)$ of patients all having focal adherence of placenta.

Previous studies had reported varying results on rate of hysterectomy and other morbidities with conservative approach with one study from France, Bretelle et al., [13] reported hysterectomy rate of $19.3 \%$ and another from the UK, Fitzpatrick et al., [14] reporting a rate of $65.6 \%$. A number of smaller studies and case reports had also reported on the safety of conservative management as Russo et al., [15]

The only statistically significant difference between conservative and radical management in terms of surgical intervention was the frequency of hemostatic sutures at the placental bed, which was higher in patients with conservative management $70.7 \%$ vs. $20.3 \%$ for radical management, respectively. Intra-operative grade distribution according to type of management. Grade 3 was present among cases with radical treatment only (30.5\%), grade $2(55.9 \%)$ managed radically while grade 1 was higher among cases with conservative management $96.9 \%$. In previous study [16] came in agreement with our study, cesarean hysterectomy was started in most of the cases of placenta increta and percerta. Conservative measures such as uterine artery ligation, tamponade and haemostatic sutures on the placental bed managed localized cases of placenta accreta. Failure of these measures led to cesarean hysterectomy. Internal artery ligation and bladder repair were performed as and when required. While the management of choice in placenta accretawas hysterectomy in most of the cases in the study by Yasmeen et al., [17] .

Concerning blood loss, there was statistically significant higher median volume blood loss, packed RBCs units, fresh frozen plasma and platelet units with radical management than with conservative management.The conservative group had a lower median volume of blood loss (4 units vs. 6 units in the radical group) and required more blood transfusions (6 packed RBCs units, 2 fresh frozen plasma units, and 2 platelet units) than the radical managed group ( 8 packed RBCs units, 3 fresh frozen plasma units and 3 platelet units) $(p<0.001)$. Similarly, Kutuk et al., recorded that total estimated blood loss, units of fresh frozen plasma used, and 
units of packed red blood cells transfused differed significantly between groups (all $p \leq 0.001$ ) [7]

Concerning maternal complications among studied cases according to type of management, there were higher incidence of complications among cases with radical management than cases with conservative management. In the current study, bladder injury represented $49.2 \%$ in radical managed group while in conservative managed group there were only $6.3 \%$ of cases of bladder injuries. Our results were higher than Elkhateeb [6] who demonstrated that there were $29.2 \%$ of cases of bladder injuries in the surgical managed group, it was relatively high number but it occurred incidentally during trial to dissect bladder downward to remove placental tissue adherent to anterior uterine wall and/or posterior bladder wall but no cases in the conservative group. In the study by Abdel Khalek et al., [7] at Menoufia Hospital $29.5 \%$ of cases had bladder injury. In another study by PriPaz et al. [19], there were $45.8 \%$ of cases with bladder injury. These differences were owing to lateral dissection of bladder from lateral to medial at Menoufia Hospital. Matsuzaki et al., [20] concluded that urologic complication occurred in $72 \%$ of cesarean hysterectomies during placenta accreta management. These urologic complications include bladder lacerations (44\%), urethral resection (6\%), and other injuries.

Our study showed that $94.9 \%$ of patients in radical group were admitted to the ICU postoperative care. This proportion showed highly significant difference when compared with the results of Abdel Khalek et al., [18], where $11.1 \%$ only were admitted to the ICU of the cesarean hysterectomies' cases. This difference between studies could be explained by demographic factors of the patients and difference in number of study population. Vinograd et al., [21] reported that $0.4 \%$ of patient with MAP had surgical wound infection.

There was statistically significant association between frequencies of NICU admission among neonates of cases with radical treatment than conservative management ( $22 \%$ versus $11.6 \%$, respectively). In comparison with a retrospective study done by Asicioglu et al., [22], to investigate patient characteristics and fetal and maternal outcomes of placenta previa and accreta (in the 5-year period from 2005 to 2010); the perinatal outcomes for 46 patients who had placenta accreta were as follows: $19.5 \%$ NICU admission and $4.3 \%$ neonatal mortality.

Conclusion: According to our study, conservative management in G1 (placenta accreta) is the recommended management option, well-planned cesarean hysterectomy in G3 (placenta percreta) is the only management option. While G2 (placenta increta) can be managed either radically or conservatively according to bleeding degree and bleeding control.

Recommendations: The present results should be confirmed with further randomized prospective trials and meta-analyses. Definitive histopathologic demonstration of the degree of placental invasion in conservatively treated cases is needed.

\section{References}

1- BAILIT J.L., GROBMAN W., RICE M.M., REDDY U.M., WAPNER R.J., VARNER M.W., LEVENO K.J., IAMS J.D., TITA A.T., SAADE G. and ROUSE D.J.: Morbidly adherent placenta treatments and outcomes. Obstetrics and Gynecology, 125 (3): 683-9, 2015.

2- FOX K.A., SHAMSHIRSAZ A.A., CARUSI D., SECORD A.A., LEE P., TURAN O.M., HULS C., ABUHAMAD A., SIMHAN H., BARTON J. and WRIGHT J.: Conservative management of morbidly adherent placenta: Expert review. American Journal of Obstetrics and Gynecology, 213 (6): 755-60, 2015.

3- FRAMARINO-DEI-MALATESTA M., D'AMELIO R., PICCIONI M.G., MARTOCCIA A. and CASORELLI A. Conservative management of placenta accreta by systemic methotrexate: Report of two cases and review of the literature. J. Clin. Case Rep., 6 (706): 2, 2016.

4- FITZPATRICK K.E., SELLERS S., SPARK P., KURINCZUK J.J., BROCKLEHURST P. and KNIGHT M.: The Management and Outcomes of Placenta Accreta, Increta, and Percreta in the United Kingdom: A Population-based Descriptive Study. Obstetric Anesthesia Digest, 35 (1): 24-5, 2015.

5- D'ANTONIO F., PALACIOS-JARAQUEMADA J., TIMOR-TRISCH I. and CALI G.: Placenta accreta spectrum disorders: Prenatal diagnosis still lacks clinical correlation. Acta Obstetricia et Gynecologica Scandinavica, 97 (7): 773-5, 2018.

6- ELKHATEEB R.: Conservative Management versus Emergency Hysterectomy in Cases of Morbidly Adherent Placenta a Retrospective Cohort Study. Austin J. Obstet. Gynecol., 5 (5): 1110-4, 2018.

7- KUTUK M.S., AK M. and OZGUN M.T.: Leaving the placenta in situ versus conservative and radical surgery in the treatment of placenta accreta spectrum disorders. International Journal of Gynecology \& Obstetrics, 140 (3): 338-44, 2018.

8- SHABAB U. and NAQVI Z.: Maternal Factors and Complications Associated with Morbidly Adherent Placenta. Journal of Surgery Pakistan (International), 22 (3): 1058, 2017.

9- CAHILL A.G., BEIGI R., HEINE R.P., SILVER R.M., WAX J.R., American College of Obstetricians and Gynecologists: Placenta accreta spectrum. American Journal of Obstetrics and Gynecology, 219 (6): 2-16, 2018. 
10- CARUSI D.A.: The placenta accreta spectrum: Epidemiology and risk factors. Clinical Obstetrics and Gynecology, 61 (4): 733-42, 2018.

11- ANOMALILERININ T.B. and DENEYIMI Y.: A single center experience on the management of placental invasion abnormalities. J. Clin. Exp. Invest www. jceionline. org Vol., 7 (1): 14-8, 2016.

12-NASRULLAH F.D., KHAN A., HAQUE S. and MUBEEN S.: Review of cases of morbidly adharent placenta in a tertiary care unit. Parity, 3 (1): 1-6, 2016.

13- BRETELLE F., COURBIÈRE B., MAZOUNI C., AGOSTINI A., CRAVELLO L., BOUBLI L., GAMERRE M. and D'ERCOLE C.: Management of placenta accreta: Morbidity and outcome. European Journal of Obstetrics \& Gynecology and Reproductive Biology, 133 (1): 34-9, 2007.

14- FITZPATRICK K.E., SELLERS S., SPARK P., KURINCZUK J.J., BROCKLEHURST P. and KNIGHT M.: The management and outcomes of placenta accreta, increta, and percreta in the UK: A population-based descriptive study. BJOG: An International Journal of Obstetrics \& Gynaecology, 121 (1): 62-71, 2014.

15- RUSSO M., KRENZ E.I., HART S.R. and KIRSCH D. Multidisciplinary approach to the management of placenta accreta. Ochsner Journal, 11 (1): 84-8, 2011.

16-WAJID R., BASHIR S. and HANIF A.: Treatment outcome of adherent placenta: An experience at tertiary care hospital. Annals of King Edward Medical University, 23 (1): 23-8, 2017.

17- YASMEEN N., AHMAD S. and BASHIR A.: Association of an increase incidence of morbidly adherent placenta with previous caesarean section and its outcomes: A 3 years analysis in a tertiary care hospital. Journal of University Medical \& Dental College, 10 (3): 1-8, 2019.

18-ABDEL-KHALEK M.E., ELHALABY A.E., ELKHOULY N.I., ANTER M.E. and ASSAF H.I.: Menoufia University Hospital experience in management of the patients with morbidly adherent placenta. Menoufia Medical Journal, 33 (2): 480-6, 2020.

19- PRI-PAZ S., FUCHS K.M., GADDIPATI S., LU Y.S., WRIGHT J.D. and DEVINE P.C.: Comparison between emergent and elective delivery in women with placenta accreta. The Journal of Maternal-Fetal\& Neonatal Medicine, 26 (10): 1007-11, 2013.

20- MATSUZAKI S., YOSHINO K., KUMASAWA K. SATOU N., MIMURA K., KANAGAWA T., UEDA Y. and KIMURA T.: Placenta percreta managed by transverse uterine fundal incision with retrograde cesarean hysterectomy: A novel surgical approach. Clinical Case Reports, 2 (6): 260-4, 2014.

21- VINOGRAD A., WAINSTOCK T., MAZOR M., MASTROLIA S.A., BEER-WEISEL R., KLAITMAN V., DUKLER D., HAMOU B., BENSHALOM-TIROSH N., VINOGRAD O. and EREZ O.: A prior placenta accreta is an independent risk factor for post-partum hemorrhage in subsequent gestations. European Journal of Obstetrics \& Gynecology and Reproductive Biology, 187 (1): 20-4, 2015 .

22- ASICIOGLU O., S AHBAZ A., GÜNGÖRDÜK K., YILDIRIM G., ASICIOGLU B.B. and ÜLKER V.: Maternal and perinatal outcomes in women with placenta praevia and accreta in teaching hospitals in Western Turkey. Journal of Obstetrics and Gynaecology, 34 (6): 462-6, 2014.

\section{العلاج التحفظى مقابل الجذرى للمشيمة شديدة الالتصاق تدقيق بحثى}

المشيمة الملتصقة (MAP)، مصطلح جديد نسبياً، يشير إلى ثلاثة أنواع محددة من المشيمة فير الطبيعية: accreta, increta, percreta.

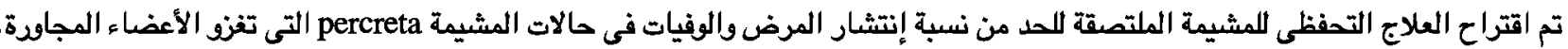

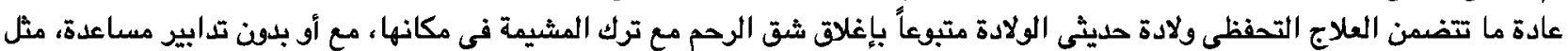

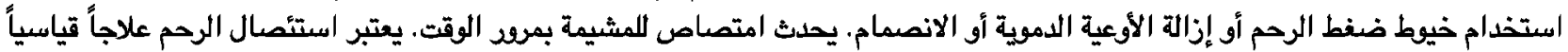

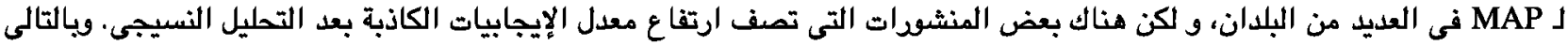

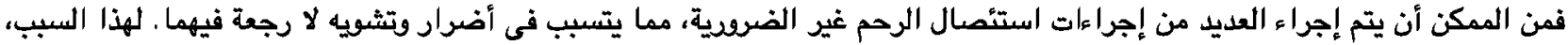

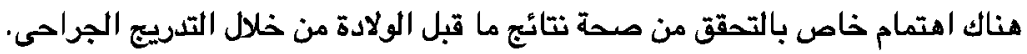

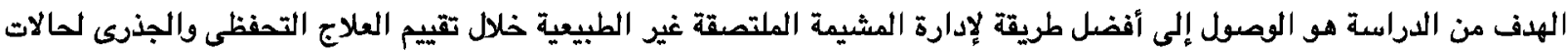

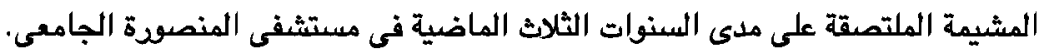

أجريت هذه الدراسة القائمة على الملاحظة بأثر رجعى باستخدام قاعدة البيانات فى قسم أمراض النساء والتوليد بمستشفى المنصودة

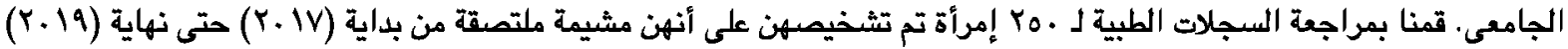

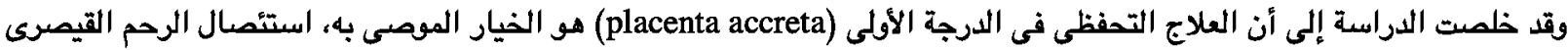

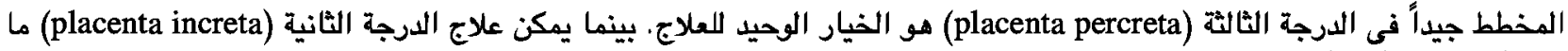
جذرياً أو تصفظياً وفقاً لدرجة النزيف والتحكم في النزيف. 